\title{
A sedimentological description of the Middle Triassic vertebrate-bearing limestone from Velika planina, the Kamnik-Savinja Alps, Slovenia
}

\author{
Luka Gale $^{1,2(*)}$, Tomaž Hitij ${ }^{3}$, Blaž Vičič ${ }^{4,5}$, Matija Križnar ${ }^{6}$, Jure Žalohar ${ }^{1,5}$, Bogomir Celarc ${ }^{2}$ \\ and Marko Vrabec ${ }^{1}$

\footnotetext{
1 University of Ljubljana, Department of Geology, Aškerčeva 12, 1000 Ljubljana, Slovenia; (luka.gale@ntf.uni-lj.si; marko.vrabec@ntf.uni-lj.si)

${ }^{2}$ Geological Survey of Slovenia, Dimičeva 14, 1000 Ljubljana, Slovenia; (luka.gale@geo-zs.si; bogomir.celarc@geo-zs.si)

3 University of Ljubljana, Faculty of Medicine, Dental School, Hrvatski trg 6, 1000 Ljubljana, Slovenia; (tomazhitij@gmail.com)

${ }^{4}$ International Centre for the Theoretical Physics, Strada Costiera 11, I-34151 Trieste, Italy;

${ }^{5}$ Quantectum AG, Churerstrasse 80, 8808 Pfäffikon, Switzerland; (jure.zalohar@guest.arnes.si; blaz.vicic@gmail.com)

${ }^{6}$ Slovenian Museum of Natural History, Prešernova 20, SI-1000 Ljubljana, Slovenia; (mkriznar@pms-lj.si)
}

doi: $10.4154 / g c .2022 .06$

Article history:

Manuscript received June 22, 2021

Revised manuscript accepted October 19, 2021

Available online January 31, 2022
Keywords: Southern Alps, intraplatform basin, Anisian, sedimentology, vertebrates, Sauropterygia

\begin{abstract}
In the Kamnik-Savinja Alps (Slovenia), the Lower Serla Dolomite laterally passes into a succession of thin- to medium-bedded bituminous limestones of the Velika planina member. The finely laminated lower part of this member contains well-preserved actinopterygian fish and sauropterygian remains. The research aimed to determine the sedimentological and palaeoenvironmental characteristics of the depositional basin on the basis of three detailed sedimentological sections logged atop the Velika planina plateau. The Velika planina member is underlain by a whitish to light grey, thick bedded to massive dolomite with oncoids, stromatolites, and lumachellas deposited under peritidal to shallow subtidal conditions. The lower part of the Velika planina member consists of thin, often platy, finely laminated beds of bituminous mudstone. The Chondrites ichnofossil is very common; however, in some beds numerous lingulid brachiopods, bivalves, and crinoids were observed. Fossil vertebrates and crustaceans are relatively rare and confined to a few levels. Ammonoids are very rare. Subordinate beds of intraclastic-peloid wackestone to packstone, intraclastic-bioclastic grainstone, and bivalve floatstone occur. Slumps are common. Upwards, bedding gradually becomes thicker and bioturbation more common. Finally, stromatolites, birdseye fenestrae, and oncoids reappear. The entire succession is confined to the early to middle Anisian by the foraminifer Citaella dinarica (KOCHANSKY-DEVIDÉ \& PANTIĆ). The absence of breccias at the base of the Velika planina member, the gradual transition upwards into shallow marine carbonates, as well as the presence of sauropterygians of the order Nothosauroidea suggest deposition in a relatively shallow basin. The finely laminated facies of the lower part of the member indicates a stratified water column, with oxygenated near-surface waters and hypoxic to anoxic conditions near the sea floor.
\end{abstract}

\section{INTRODUCTION}

The Triassic was an important period for the recovery of life on Earth after the end-Permian extinction. Not only were new ecosystems established, but new animal lineages came to play key roles in the emerging Modern Evolutionary Fauna (PAYNE \& VAN DE SCHOOTBRUGGE, 2007; BENTON, 2016; BUATOIS et al., 2016). Among such groups were also the actinopterygian fishes (TINTORI et al., 2014a, b) and marine reptiles (MOTANI, 2009; STUBBS \& BENTON, 2016; BRAYARD et al., 2017). The most famous finds of the latter come from the classic deposits of the Germanic Basin (RIEPPEL, 1999; HAGDORN \& RIEPPEL, 1999; DIEDRICH, 2012), and the Southern Alps of the Monte San Giorgio area (FURRER, 1995a; RÖHL et al., 2001; STOCKAR, 2010; HUGI et al., 2011; FURRER \& VANDELLI, 2014; RENESTO et al., 2014; BEARDMORE \& FURRER, 2016, 2019), as well as from more recently discovered sites in southern China (LIU et al., 2011; BENTON et al., 2013).

As recently as 20 years ago, reports of sauropterygians from the Triassic beds of Slovenia were scarce. DEECKE (1886) mentioned remains of a marine reptile collected from the scree below Mt. Storžič in the Kamnik-Savinja Alps. The fossil was later de- scribed as a pachypleurosaur of the Serpianosaurus - Neusticosaurus clade (RIEPPEL, 1997). More than two centuries later, new discoveries started to emerge: a placodont dentary bone from the upper Ladinian or lower Carnian beds of Toško Čelo near Ljubljana (BUFFETAUT \& NOVAK, 2008), isolated bones and teeth of sauropterygians from the Carnian shallow marine deposits in the Poljane Valley (KRIŽNAR, 2009), pachypleurosaur, placodont, and ichthyosaur bones from the Anisian Strelovec Formation (HITIJ \& RENESTO, 2010), and sauropterygian bones from the Ladinian Buchenstein Formation in the Kamnik-Savinja Alps and the Southern Karavanke Mountains (HITIJ et al., 2010b). However, most of the new finds of sauropterygians came from the Anisian beds of the Velika planina member on the Velika planina mountain plateau (Fig. 1), where they occur together with a number of actinopterygian fish genera of the so-called "Early Anisian Fish Fauna" (HITIJ et al., 2010a; TINTORI et al., 2014a). Despite the importance of these finds and the large potential for future palaeontological research, the stratigraphic position of the Velika planina member remains poorly constrained, with no information on its lower and upper boundaries. Moreover, the sedimentological composition of the member as a whole and its microfacies association have not been previously described. 


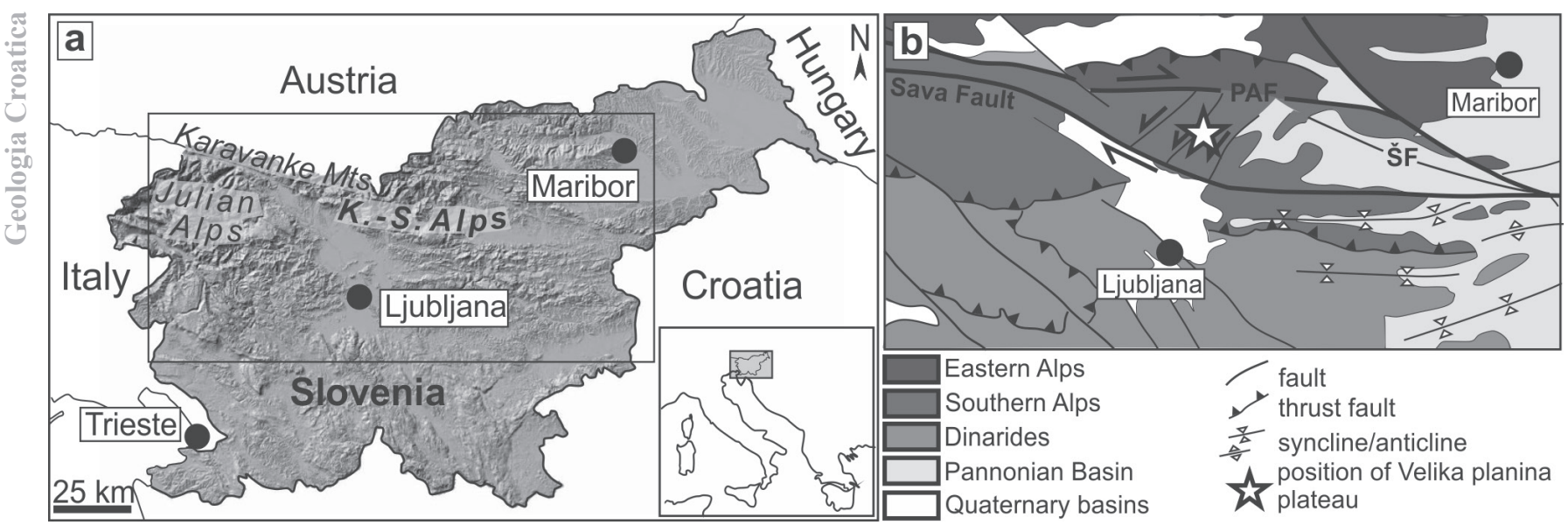

Figure 1. Geographical and structural position of the Velika planina plateau. a Map of Slovenia with the location of the Kamnik-Savinja Alps. The smaller rectangle shows the position of the inset in Figure 1b. Source: Digital elevation model with $5 \times 5 \mathrm{~m}$ raster grid, DEM 5, 2006. Slovenia, Public Information of Slovenia, The Surveying and Mapping Authority of the Republic of Slovenia. b The tectonic structure of central and northern Slovenia. The position of the Velika planina plateau is indicated by a star symbol. PAF: Periadriatic Fault. ŠF: Šoštanj Fault. Modified after VRABEC \& FODOR (2006).

The aim of this paper is to fill this gap by presenting several key sections of the Velika planina member. We provide direct evidence for the early to middle Anisian age of the member on the basis of determinations of foraminifers. Based on the detailed description of microfacies associations and currently known fossils from this member, we try to provide some answers about the relative depth of the depositional area, the type of sedimentation, and the palaeoenvironmental conditions on the sea floor.

\section{STRUCTURAL SETTING OF THE KAMNIK- SAVINJA ALPS}

Velika planina is a karstified mountain plateau with an average altitude of $1500 \mathrm{~m}$, located in the southern part of the KamnikSavinja Alps (Fig. 1). In terms of regional tectonic structure, the Kamnik-Savinja Alps belong to the eastern Southern Alps, shaped during the Cretaceous to Cenozoic Alpine orogeny (PLACER, 1999; SCHMID et al., 2008). Together with the Southern Karavanke Mountains, they represent a mega shear lens between two major dextral strike-slip faults in the Periadriatic Fault Zone: the Periadriatic Fault to the north and the Sava Fault to the south. While the main, northern branch of the Periadriatic Fault formed during the Oligocene and was later reactivated several times, the main movements along the Sava Fault took place after the latest Miocene (VRABEC \& FODOR, 2006). The two dextral strikeslip faults are connected by left strike-slip faults running in NE$\mathrm{SW}$ directions. Palaeomagnetic directions from Oligocene to Neogene sediments indicate domino-like block rotations along these faults (FODOR et al., 1998; VRABEC \& FODOR, 2006; VRA$\mathrm{BEC}$ et al., 2006). Prior to the formation of the shear zone, the area experienced two major phases of thrusting: the NE - SW directed Eocene-Oligocene thrusts preceded the $\mathrm{N}-\mathrm{S}$ directed Miocene - recent thrusts (PLACER, 1999; PONTON, 2014). In the central part of the Kamnik-Savinja Alps, MIOČ et al. (1983) distinguished the so-called Savinja Thrust overlying the Southern Karavanke Thrust. CELARC (2004) later found no evidence of a thrust in the northern part of the Kamnik-Savinja Alps, which called into question the existence of the Savinja Thrust in that area. DOLZZAN (2017) recently confirmed the existence of a detachment surface (named the Kočna Detachment Surface, KDS) in the central Kamnik-Savinja Alps, dipping $8^{\circ}$ to the E. However, no evidence for thrusting was found, and the KDS was interpreted as a low-angle normal fault, that is towards the NW successively lowered along normal faults until it is no longer exposed.

\section{TRIASSIC STRATIGRAPHY OF THE KAMNIK- SAVINJA ALPS}

Systematic geological research of the Kamnik-Savinja Alps started in the second half of the 19th century (LIPOLD, 1856; ROLLE, 1857; TELLER, 1885, 1898 a, b). Modern geological maps were produced by BUSER and CAJHEN (1977), MIOČ et al. (1983), PREMRU (1983a), and CELARC (2004). Accompanying explanatory books were written by BUSER (1980), MIOČ (1983), and PREMRU (1983b). Stratigraphic research, focused on Triassic deposits, was carried out by RAMOVŠ (1973), JURKOVŠEK (1984), GORIČAN \& BUSER (1990), RAMOVŠ \& JAMNIK (1991), CELARC (2004), CELARC \& GORIČAN (2007), CELARC et al. (2013, 2014). The Triassic succession preserved in the Kamnik-Savinja Alps first reflects the existence of a mixed siliciclastic - carbonate ramp in the Early Triassic and then the gradual establishment of a flat and uniform carbonate platform, the formation of various smaller intraplatform basins with accompanying volcanism from the Anisian until the Late Ladinian, regional drowning in the Late Carnian, and progradation of the platform in the Norian (BUSER, 1989, 1996). The development took place at the western passive margin of equatorial Pangea, close to the Palaeotethys and from the Middle Triassic onwards also next to the Neotethys Ocean (HAAS et al., 1995; STAMPFLI \& BOREL, 2002; STAMPFLI \& KOZUR, 2006). In the Kamnik-Savinja Alps the Lower Triassic is represented by sandstones, marly limestone, and oolitic limestone belonging to the Werfen Formation (Fig. 2). This gradually passes into the lower Anisian dolomite (or limestone), equivalent to the Lower Serla Dolomite in the central Southern Alps (GIANOLLA et al., 1998). The Lower Serla Dolomite laterally and vertically passes into a succession of thin- to medium-bedded, locally finely laminated bituminous limestone several tens of metres thick, here referred to as the Velika planina member. The unit locally contains isolated bones and partial to complete vertebrate skeletons. On the Velika planina plateau, the Velika planina member gradually passes upwards into medium-bedded and then massive limestone and dolomite still belonging to the Lower Serla Dolomite. On the Velika planina plateau, this dolomite is in a faulted contact with the limestone and dolomite of the Schlern Formation. Elsewhere in the Kamnik-Savinja Alps (as well as in parts of the Julian Alps), where the contact is not disturbed by younger faults, the Lower Serla Dolomite passes upwards into a unit of 


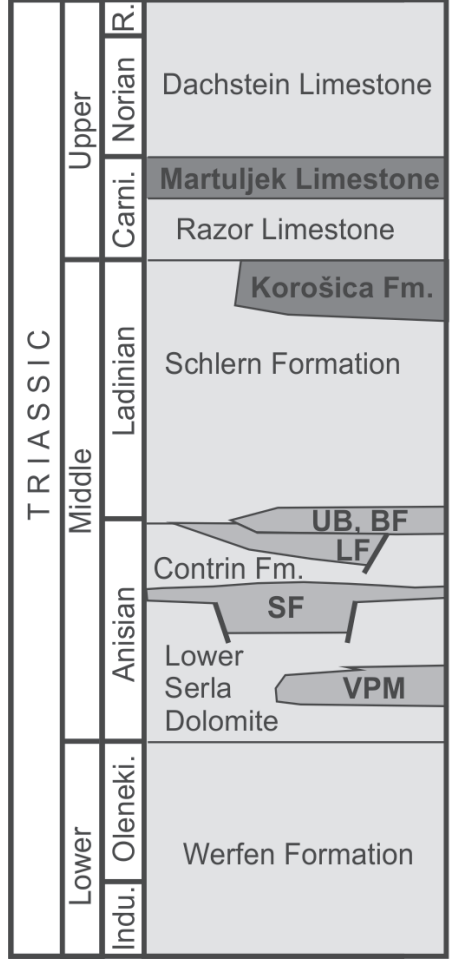

BF: Buchenstein Formation

UB: Uggowitz Breccia

LF: Ljubelj Formation

SF: Strelovec Formation

VPM: Velika planina member

shallow marine

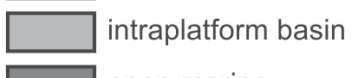

Figure 2. Stratigraphic column of the Triassic in the Kamnik-Savinja Alps. Modified after ŽALOHAR \& CELARC (2010).

marlstone, mudstone, thin- to medium-thick bedded limestone and dolomite of the middle to upper Anisian (Pelsonian - early Illyrian) Strelovec Formation which is up to $60 \mathrm{~m}$ thick (CELARC et al., 2013; MIKLAVC et al., 2016; PRIMOŽIČ, 2020). The Strelovec Formation is concordantly overlain by the upper Anisian Contrin Formation, comprising shallow marine bedded and massive limestone, or locally dolomite (CELARC et al., 2013). The Contrin Formation is locally dissected by palaeofaults. Small half-grabens are filled with red radiolarian-bearing limestones of the Illyrian Loibl (Ljubelj) Formation, volcanic and volcaniclastic rocks, polymict breccias, and conglomerates (equivalent to the Ugovizza/Uggowitz Breccia), marls, and hemipelagic limestones (equivalent to the Buchenstein/Livinallongo Formation). Upwards follow several hundred metres of massive limestone of the Ladinian Schlern Formation (CELARC et al., 2013). The growth of the Schlern platform was interrupted during the late Ladinian (Longobardian). Volcaniclastics, platy limestone with chert, and calcarenites of the Korošica Formation were locally deposited (JURKOVŠEK, 1984; CELARC, 2004; ŽALOHAR \& CELARC, 2010). Elsewhere, the top of the Schlern Formation is marked by breccias, indicating a stratigraphic gap between the Schlern Formation and the lower Carnian peritidal Razor Limestone. During the late Carnian, approximately $25 \mathrm{~m}$ of hemipelagic Martuljek Platy Limestone was deposited. In distal positions relative to the prograding Dachstein platform approximately $150 \mathrm{~m}$ of lower Norian limestone with chert follows. Finally, after a narrow prograding reef margin, a thick succession of peritidal limestones of the Dachstein Formation deposited over the wider area (CELARC et al., 2013).

\section{GEOLOGICAL MAP AND SETTING OF THE VELIKA PLANINA PLATEAU}

Geological maps of the Velika planina mountain plateau were produced by TELLER (1898a, b), and PREMRU (1983a, b). Reambulation of the geological map covering the research area was performed by one of the authors of the paper (B.V.) in 2014. The southern part of the Velika planina plateau is dominated by Middle Triassic carbonates, i.e. the Anisian Lower Serla Dolomite and the Velika planina member (Fig. 3). To the north, these two Anisian units are in faulted contact with the younger shallow marine dolomites and subordinate limestones of the Ladinian Schlern Formation. To the south, the Lower Serla Dolomite is in normal stratigraphic contact with the Lower Triassic Werfen Formation. The latter is thrusted over the Middle Triassic dolomite. Lineation on the thrust plane indicates initial thrusting to the SW, overprinted by younger thrusting to the $\mathrm{S}$. The area is additionally transected by steep faults of SSW-NNE, NE-SW, NEE-SWW, and NW-SE strikes, respectively. We were unable to determine whether some of these are reactivated synsedimentary faults.

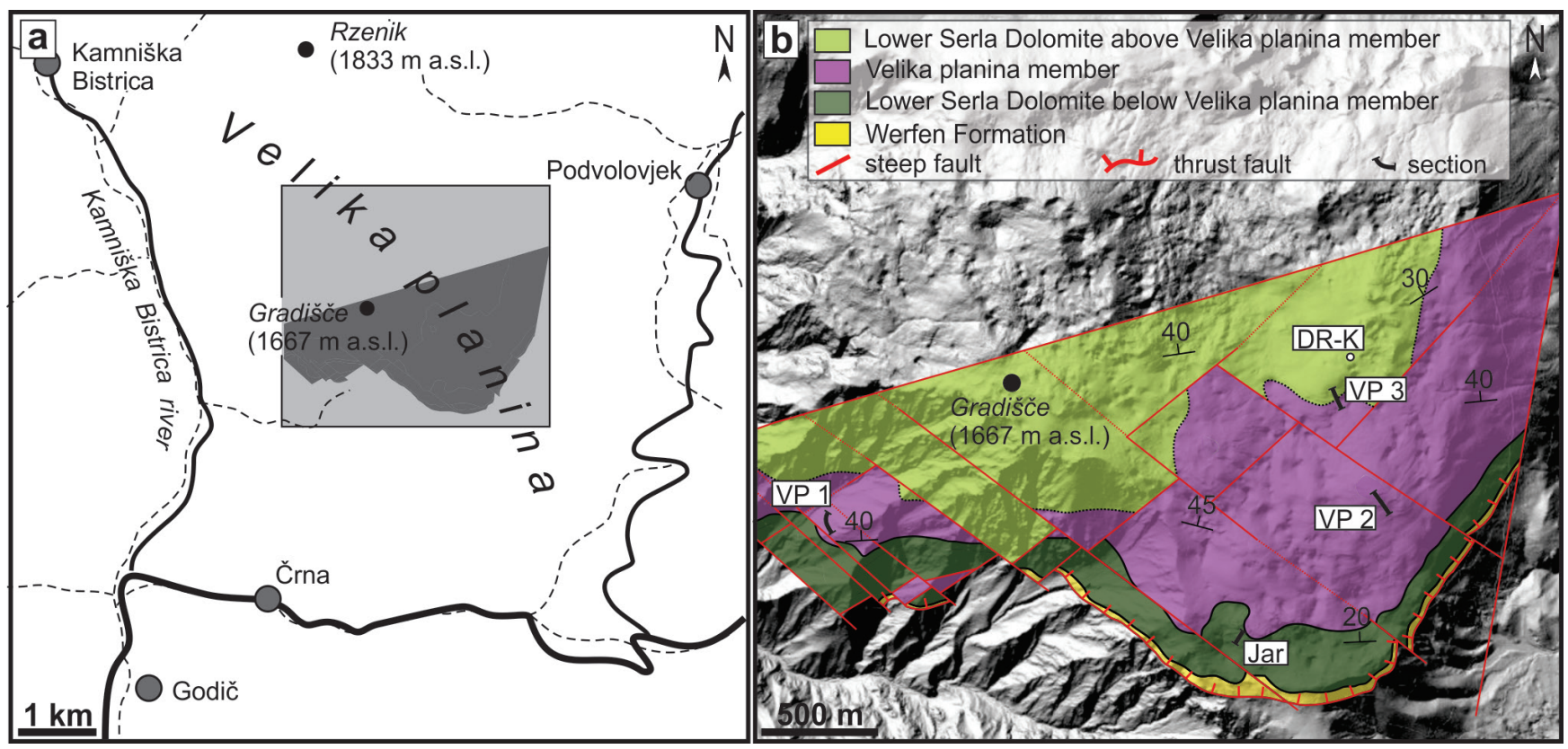

Figure 3. Geological map of part of the Velika planina plateau. a) Position of the studied area. b) Geological map and position of the sections. 


\section{MATERIALS AND METHODS}

The Velika planina member was logged and sampled in three sections on top of the Velika planina plateau (Figs. 3-4). In addition, samples from the Lower Serla Dolomite below the Velika planina member were collected from outcrops at the "Jarški dom" hut (samples Jar 1-17 on Fig. 4), and an additional sample from a massive limestone overlying the Velika planina member was taken at "Dovja raven" (sample DR-K). Altogether, 71 thin-sections $28 \times$ $47 \mathrm{~mm}$ in size were made. Selected thin-sections were stained with Alizarin Red. Textures were defined according to classifications by DUNHAM (1962), and EMBRY \& KLOVAN (1971). In determining floatstone, we follow the criteria of WRIGHT (1992), considering matrix as mud to silt-sized grains. Textures were also

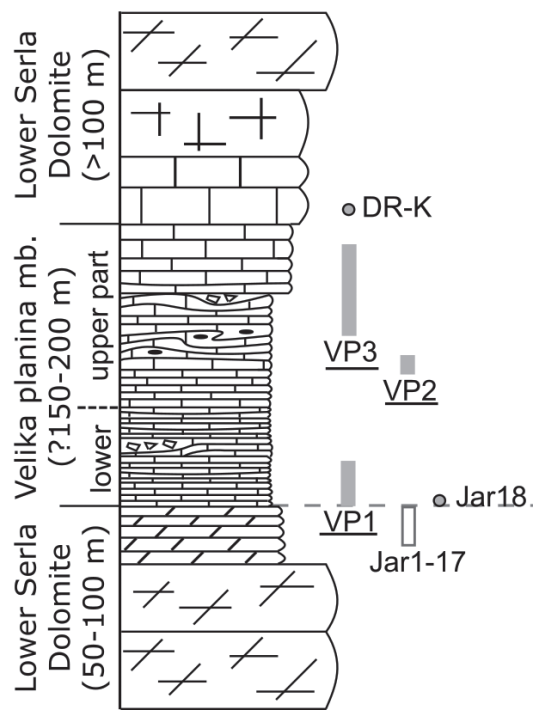

Figure 4. Schematic stratigraphic column with relative positions of samples and sections. defined based on a comparison with examples in FLÜGEL (2010). When adding the constituents to the name of the carbonate, we follow the reverse ranking order, putting the dominant component first (e.g. packstone dominated by bioclasts and with subordinate intraclasts was named bio-intraclastic packstone), as suggested by WRIGHT (1992). The fossil material was collected from several outcrops of the Velika planina member. All specimens are housed within the Hitij \& Žalohar Palaeontological Collection, curated, and registered according to Slovenian legislation in the Slovenian Museum of Natural History, Ljubljana, Slovenia.

\section{LITHOLOGICAL COMPOSITION OF THE STUDIED SECTIONS}

\section{Lower Serla Dolomite}

The Velika planina member is underlain by whitish to light grey thick bedded to massive dolomite some $100 \mathrm{~m}$ thick, sampled at the locality "Jar" (see Fig. 3). The dolomite macroscopically contains numerous oncoids, stromatolites, bivalve and gastropod lumachellas. Several foraminifers, including Citaella dinarica (Kochansky-Devidé \& Pantić) have been found in several microfacies types. Microfacies types comprise mudstone, partly washed bioclastic wackestone, partly washed intraclastic-bioclastic wackestone to packstone, dolomitized dasycladacean grainstone, microbial intraclastic rudstone, dolomitized bivalve rudstone, microbialite boundstone, and microbialite wackestone or bafflestone (Table 1; Fig. 5).

\section{Velika planina member - section VP1}

The transition from light grey Lower Serla Dolomite into darker, thinner, and finely laminated limestone beds of the Velika planina member appears to be gradual. The basal part of the Velika planina member was logged in the $26 \mathrm{~m}$ long section VP1 (Fig. 6). Platy to thin-bedded dark bituminous and finely laminated micritic limestone predominates. Slumps are common. Subordinate are

Table 1. Microfacies types of the Lower Serla Dolomite (locality Jar on Fig. 3, and samples Jar 1-17 on Fig. 4).

\begin{tabular}{|c|c|c|}
\hline Microfacies & Description & Figures \\
\hline Mudstone & $\begin{array}{l}\text { Micrite containing very rare ostracods, micritic tubular fossils and echinoderms. Some dissolution voids are present. Gradually passes into } \\
\text { bioclastic wackestone. }\end{array}$ & I \\
\hline $\begin{array}{l}\text { Partly washed } \\
\text { bioclastic } \\
\text { wackestone }\end{array}$ & $\begin{array}{l}\text { Clasts represent approximately } 30 \% \text { of the area. Most are probably bioclasts, replaced by drusy mosaic cement. Bivalve shells can be } \\
\text { recognised besides smaller oval bioclasts. Shells are encrusted by microbialite. Echinoderms, rimmed with syntaxial cement, are very rare, as } \\
\text { well as ostracods. Approximately } 30 \% \text { of the grains are microbialite intraclasts. The intergranular space is filled with brown dolomicrospar, } \\
\text { locally containing small pellets (microbial in origin?). Dissolution voids are filled with large elongated crystals of carbonate. }\end{array}$ & $5 a$ \\
\hline $\begin{array}{l}\text { Partly washed } \\
\text { intraclastic-bioclastic } \\
\text { wackestone to } \\
\text { packstone (?) }\end{array}$ & $\begin{array}{l}\text { Texture is heterogenous. Grains occupy } 20-50 \% \text { of the thin section area. Predominant are microbialite intraclasts (estimated } 75 \% \text { of the } \\
\text { grains). Bioclasts are casts of shell fragments and geniculi of dasycladacean algae, filled by sparry calcite, echinoderm plates, and foraminifers } \\
\text { (Endotebanella kocaeliensis (Dager), ?Earlandinita sp., ?Citaella dinarica (Kochansky-Devidé \& Pantić), Nodosaria ordinata Trifonova, ?Duosto- } \\
\text { minidae). The intergranular space is filled with microsparite, which is partly washed out and/or corroded. Echinoderm plates are overgrown by } \\
\text { syntaxial cement. }\end{array}$ & $5 b$ \\
\hline $\begin{array}{l}\text { Dolomitized } \\
\text { dasycladacean (?) } \\
\text { grainstone }\end{array}$ & $\begin{array}{l}\text { Rounded recrystallized grains represent } 40-50 \% \text { of the total thin section area. They are in point contacts and often stuck together in bundles. } \\
\text { Individual grains are } 0.9-1.3 \mathrm{~mm} \text { in diameter. The majority of them could belong to dasycladacean algae. Alternatively, some smaller grains } \\
\text { could also be interpreted as ooids. The intergranular space is filled by dolomicrosparite and anhedral to subhedral dolomite. }\end{array}$ & $5 c$ \\
\hline $\begin{array}{l}\text { Microbial intraclastic } \\
\text { rudstone }\end{array}$ & $\begin{array}{l}\text { Intraclasts larger than } 2 \mathrm{~mm} \text { represent up to } 20 \% \text { of the thin section area. Most belong to microbialite (thrombolite and leiolite). Large grains } \\
\text { are supported by the grainstone in which smaller microbialite intraclasts and peloids predominate. Very rare are ostracods ( } 2.5 \%) \text {, foraminifers } \\
(0.5 \% \text {; Trochammina almtalensis Koehn-Zaninetti, ? Endotriadella sp., Citaella dinarica (Kochansky-Devidé \& Pantić), sessile foraminifers with } \\
\text { dark micritised walls), echinoderms and bivalves }(0.5 \%) \text {. The intergranular space is filled by anhedral to subhedral carbonate. Echinoderm } \\
\text { plates are overgrown by syntaxial cement. Cockade textures are locally common. They are filled with zoned euhedral dolomite crystals. }\end{array}$ & $5 d-e$ \\
\hline $\begin{array}{l}\text { Dolomitized bivalve } \\
\text { rudstone }\end{array}$ & $\begin{array}{l}\text { Bivalve shells larger than } 1 \mathrm{~cm} \text { occupy } 40 \% \text { of the area. Shells are replaced by dolomite cement. The supporting grainstone is nearly identical in } \\
\text { composition to the intraclastic grainstone described above. Citaella dinarica (Kochansky-Devidé \& Pantić), Earlandinita sp. and sessile foraminifers } \\
\text { were determined among microfossils. Small gastropods are also present. Fibrous to acicular rim cement precedes drusy mosaic spar. }\end{array}$ & $5 f$ \\
\hline $\begin{array}{l}\text { Microbialite } \\
\text { boundstone }\end{array}$ & $\begin{array}{l}\text { The sample is interpreted as microbialite boundstone with intraclastic wackestone matrix. Microbial carbonate forms irregular clusters. The } \\
\text { intergranular space is filled by microspar, whereas some fenestrae are filled with true spar. Besides the larger microbialite clumps/clasts, it } \\
\text { contains smaller echinoderms, foraminifers (Trochammina almtalensis Koehn-Zaninetti, Earlandia sp.), and bivalve shells. }\end{array}$ & $5 g$ \\
\hline $\begin{array}{l}\text { Microbialite } \\
\text { wackestone } \\
\text { or bafflestone }\end{array}$ & $\begin{array}{l}\text { Branching clasts of microbialite are surrounded by microspar. The microsparitic matrix locally contains larger irregular cavities filled with } \\
\text { elongated calcite, followed by subhedral drusy mosaic cement. Complete bivalves and calcimicrobes are rarely preserved. The microbialite } \\
\text { embeds an unknown organism, which either had no skeleton or had a skeleton that later dissolved and was replaced by spar. The remaining } \\
\text { shape reveals a tubular shape, a smooth inner side, and an irregular outer surface. }\end{array}$ & $5 h$ \\
\hline
\end{tabular}



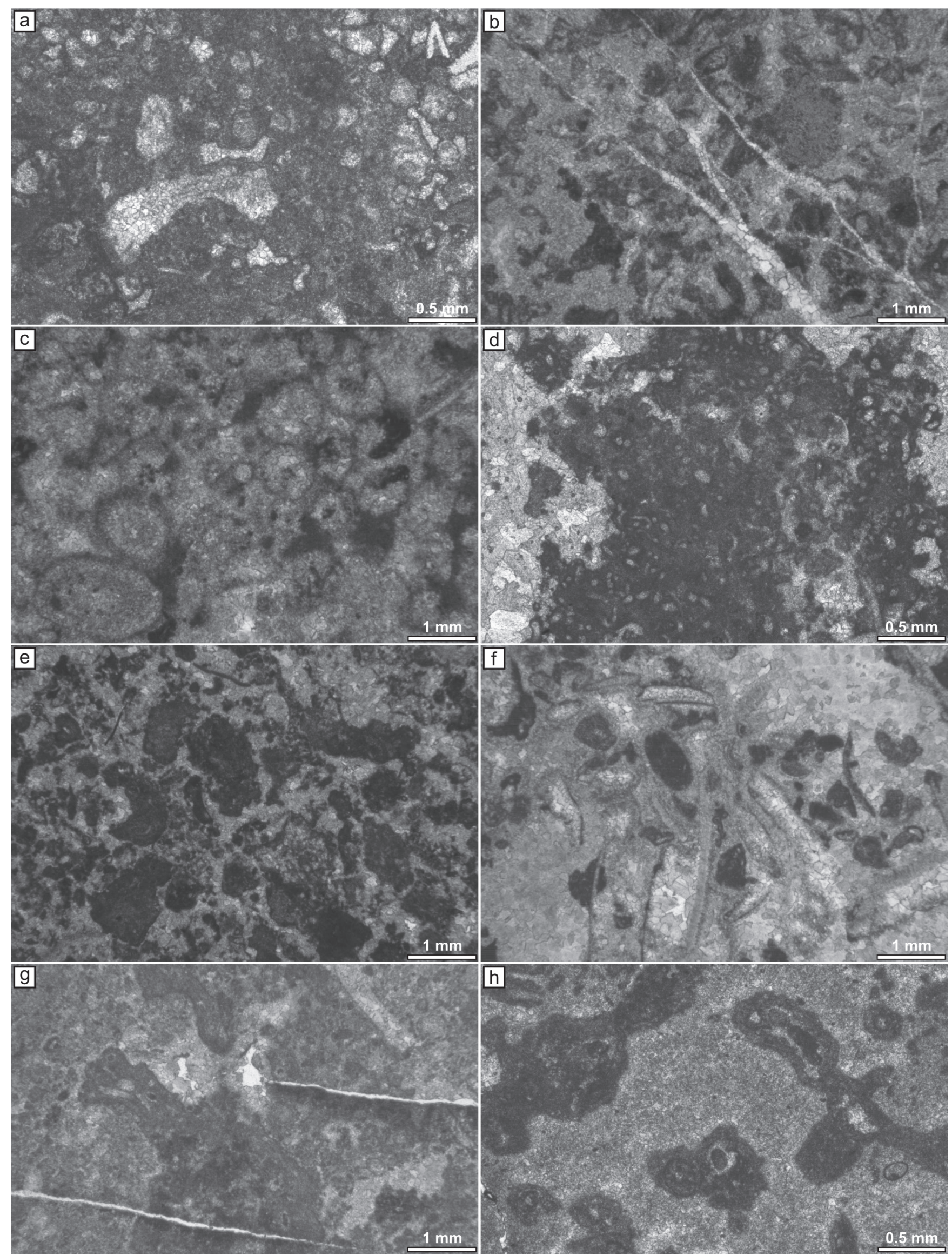

Figure 5. Microfacies of the Lower Serla Dolomite. a) Partly washed bioclastic wackestone. Thin section 1490. b) Partly washed intraclastic-bioclastic wackestone to packstone. Thin section 1496. c) Dolomitized dasycladacean (?) grainstone. Thin section 1486. d) Large microbialite intraclast within a microbial intraclastic rudstone. Thin section 1495. e) Intraclastic grainstone matrix of a microbial intraclastic rudstone. Thin section 1497. f) Dolomitized bivalve rudstone. Thin section 1493. g) Microbialite boundstone. Thin section 1501. h) Microbialite wackestone or bafflestone. Thin section 1488. 
beds of calcarenite up to $15 \mathrm{~cm}$ thick, which are lighter in colour and without lamination. Seven microfacies types are determined, namely mudstone, finely laminated mudstone, Earlandia mudstone, peloid wackestone with ostracods, partly washed intraclastic-peloid wackestone to packstone, intraclastic-bioclastic grainstone, and bivalve floatstone (Table 2; Fig. 7). Small-scale bioturbations are locally present.

\section{Velika planina member - section VP2}

Section VP2 comprises dark brown to almost black micritic limestone $10.5 \mathrm{~m}$ thick in total. Most beds are thicker than in section VP1 from the lowermost part of the member, measuring between $15 \mathrm{~cm}$ and $1 \mathrm{~m}$ in thickness. Lamination is commonly present, but the laminae are also much thicker (approximately $1 \mathrm{~cm}$ ). Subordinate are platy to thin-bedded beds with finer lamination, which no

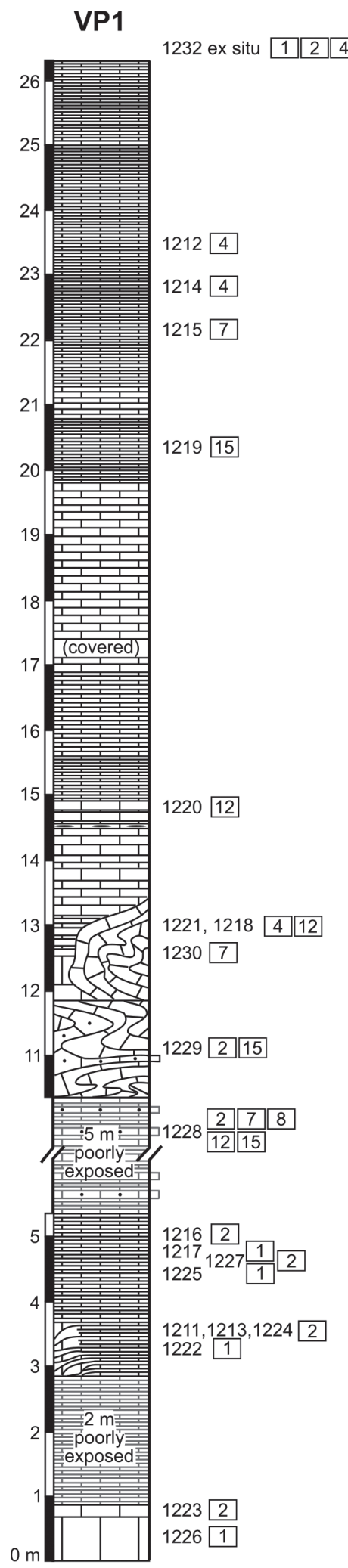

VP2

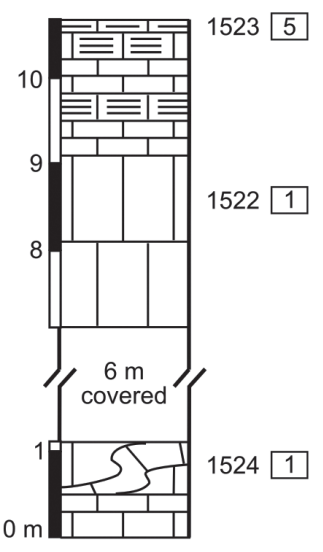

㤟吅 breccia

․?. calcarenite

Hicritic limestone

5) slump

\%OO onkoids

$\equiv$ lamination

Microfacies types

1 mudstone

2 finely laminated mudstone

3 stromatolite

4 Earlandia mudstone

5 mudsstone with filaments \&

sessile foraminifers

6 bioturb. m. with bioclasts

7 ostracod-peloid wackest.

8 partly washed intraclast.-

9 partly washed bioclastic-

10 bioclastic-peloid $\mathrm{w}$.

11 bioclastic-peloid g.

12 bioclastic-intraclast. $g$.

13 intraclastic.-bioclastic g.

14 oncoid floatstone

15 bivalve rudstone

16 breccia

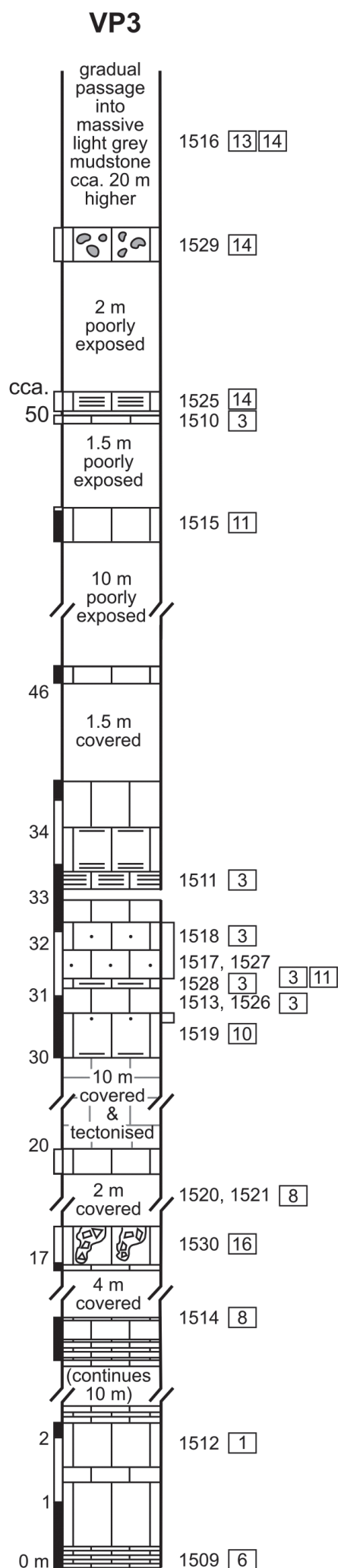


Table 2. Microfacies types of the lower Velika planina member (section VP1). *The number in brackets refers to the microfacies type number in Fig. 6.

\begin{tabular}{|c|c|c|}
\hline Microfacies & Description & Figures \\
\hline Mudstone $\left({ }^{*} 1\right)$ & Micritic matrix is recrystallised into microsparite. Ostracods and bioturbations are very rarely present. & / \\
\hline $\begin{array}{l}\text { Finely laminated } \\
\text { mudstone }\left({ }^{*} 2\right)\end{array}$ & $\begin{array}{l}\text { The microsparite is finely laminated. Laminae are mostly horizontal and parallel to each other, between } 0.05 \mathrm{~mm} \text { and } 2.51 \mathrm{~mm} \text { thick. In some } \\
\text { samples, they are deformed as a result of slumping. The grey-coloured laminae are separated by thinner, } 0.04-0.48 \mathrm{~mm} \text { thick laminae of } \\
\text { darker micrite or microsparite. Besides laminae of mudstone, some rare sparse wackestone laminae up to } 1 \mathrm{~cm} \text { thick with very small peloids, } \\
\text { foraminifers (?Earlandia sp., Nodosaria ordinata Trifonova, Miliolida), ostracods or thin-shelled bivalves are present. Microsparite locally } \\
\text { contains rhomboidal crystals of calcite. They are more common in the darker laminae. Lamination follows the outlines of the crystals. One } \\
\text { sample contained elliptical horizontal and vertical burrows filled with pellets and cutting through the laminae. Small-scale synsedimentary } \\
\text { faults are locally present. Some samples are stylolitised concordant or oblique to the bedding planes. }\end{array}$ & $7 a$ \\
\hline $\begin{array}{l}\text { Earlandia mudstone } \\
\left({ }^{*} 4\right)\end{array}$ & $\begin{array}{l}\text { Micritic matrix is laminated. Laminae are slightly wrinkled. They are wider and more uniformly dark than in MF 1. The presence of Earlandia } \\
\text { tintinniformis (Mišik) is characteristic, especially in slightly darker laminae. Other foraminifers (Nodosaria ordinata Trifonova) and ostracods are } \\
\text { rarely present. }\end{array}$ & $7 \mathrm{~b}$ \\
\hline $\begin{array}{l}\text { Peloid wackestone } \\
\text { with ostracods }\left({ }^{*} 7\right)\end{array}$ & $\begin{array}{l}\text { Grains represent } 25-40 \% \text { of the area. Peloids and intraclasts represent } 15-20 \% \text { of the area. Ostracods with complete carapaces or separated } \\
\text { valves are always present (8-15\% of the area). Filaments, echinoderm plates, and foraminifers (Earlandia tintinniformis (Mišik), Nodosaria } \\
\text { ordinata Trifonova, Glomospira sp., Endotriada sp., Trochammina sp.) are rarer. Micritic matrix is locally recrystallised into microspar. }\end{array}$ & 7c \\
\hline $\begin{array}{l}\text { Partly washed } \\
\text { intraclastic-peloid } \\
\text { wackestone to } \\
\text { packstone }\left({ }^{*} 8\right)\end{array}$ & $\begin{array}{l}\text { Grains represent } 30-50 \% \text { of the area. They are moderately to poorly sorted: the mean grain size is } 0.15 \mathrm{~mm} \text {, while the largest reach sizes up to } \\
5.3 \mathrm{~mm} \text {. Peloids and micritic intraclasts strongly predominate. Ostracods, echinoderms, foraminifers (Endoteba sp., ? Earlandia sp.), fragments } \\
\text { of brachiopods and bivalve shells (casts filled with sparry calcite) are very rare. Micritic matrix is partly washed out, and part of the intergranu- } \\
\text { lar space is filled with drusy mosaic calcite. Echinoderm plates are overgrown by syntaxial calcite cement. } \\
\text { Note: Similar microfacies was sampled in section VP3. }\end{array}$ & $7 d$ \\
\hline $\begin{array}{l}\text { Intraclastic-bioclastic } \\
\text { grainstone (?) }\left({ }^{*} 11\right)\end{array}$ & $\begin{array}{l}\text { Grains are moderately well sorted. They represent } 50 \% \text { of the area and are in point contacts. Their mean size is approximately } 0.15-0.2 \mathrm{~mm} \text {. } \\
\text { Small micritic intraclasts and pelletoids predominate ( } 35 \% \text { of area). Rare coated grains built by sessile foraminifers and microbialites are also } \\
\text { recognisable. Particles with micritised margins and filled with sparry calcite occupy approximately } 7 \% \text { of the area. Foraminifers ( } 3 \%) \text {, } \\
\text { echinoderms (3\%) and ostracods are less common. The foraminifers are Glomospira sp., Endotriada tyrrhenica Vachard et al., Endoteba bitynica } \\
\text { Vachard et al., Earlandia gracilis (Pantić). The cement is subhedral, probably drusy mosaic calcite. }\end{array}$ & 7e \\
\hline $\begin{array}{l}\text { Bivalve floatstone } \\
\left({ }^{*} 14\right)\end{array}$ & $\begin{array}{l}\text { The dominant bioclasts are bivalve shells. They are in point or long contacts. Bivalves are mostly disarticulated, but the valves are not } \\
\text { fragmented, up to } 2 \mathrm{~cm} \text { long. Gastropods are rarely present. The intergranular space is filled with micritic matrix. }\end{array}$ & $7 f$ \\
\hline
\end{tabular}

Table 3. Microfacies types of the middle Velika planina member (section VP2). ${ }^{*}$ The number in brackets refers to the microfacies type number in Fig. 6.

\begin{tabular}{ll}
\hline Microfacies & Description \\
\hline Mudstone $\left({ }^{*} 1\right)$ & See description in Table 2. \\
\hline Mudstone with filaments and sessile foraminifers $\left.{ }^{*} 5\right)$ & Disarticulated thin-shelled bivalves with attached sessile foraminifers float in micritic matrix, recrystallized into microspar. \\
\hline
\end{tabular}

Table 4. Microfacies types of the upper Velika planina member (section VP3). *The number in brackets refers to the microfacies type number in Fig. 6.

\begin{tabular}{ll}
\hline Microfacies & Description \\
$\begin{array}{l}\text { Bioturbated mudstone } \\
\text { with sparse bioclasts }\left({ }^{*} 6\right)\end{array}$ & Micritic matrix predominates. Elongated lenses of microspar suggest bioturbation. Rare bivalves and unidentified shells are present. \\
\hline $\begin{array}{l}\text { Microbial laminated } \\
\text { mudstone (stromatolite) } \\
(* 3 a)\end{array}$ & $\begin{array}{l}\text { Micritic limestone exhibit light and dark brown sub-millimetre thick laminae. The darkest laminae have wavy or even more irregular } \\
\text { upper surfaces and consist of dense micrite. The wider and lighter laminae are mudstone or pellet packstone. Pellet grainstone is } \\
\text { locally present, as well as fenestrae. }\end{array}$ \\
\hline $\begin{array}{l}\text { Microbially-bound } \\
\text { grainstone with fenestral }\end{array}$ & $\begin{array}{l}\text { Microbalite laminae are dense, structureless, or made of clots of dark micrite. Desiccation cracks and fenestrae are locally present. } \\
\text { Microbialite binds grainstone with peloids and/or particles of dissolved and neomorphically replaced bioclasts. Foraminifers }\end{array}$
\end{tabular}
fabric (stromatolite) (*3b) (?Glomospirella irregularis (Moeller)) are locally present.

Partly washed intraclastic- See description in Table 2. Foraminifers in this part are: Glomospira sp, ?Palaeolituonella meridionalis (Luperto), ?Endotebanella sp. \begin{tabular}{ll} 
peloid wackestone to & See description in Table 2. Foraminifers in this part are: Glomospira sp., ?Palaeolit \\
\hline
\end{tabular} packstone $\left({ }^{*} 8\right)$

Peloid wackestone (*9) Micritic matrix predominates. Angular to subangular peloids represent $15 \%$ of the thin section area. Subrounded to rounded sparitic grains are also present. Foraminifers (Glomospira sp., Earlandia sp.) are very rare. Grains occupy $65 \%$ of the total area. They are in point contacts. The prevailing grain size is around $0.15 \mathrm{~mm}$ (ranges between $0.03 \mathrm{~mm}$ Bioclastic-peloid grainstone and $0.7 \mathrm{~mm}$ ). The most common grains are subrounded to rounded sparitic bioclasts ( $45 \%$ of the area), which may have been (*10) leached-out and replaced by spar. The rest of the grains are peloids ( $20 \%$ of the area), which are subangular to angular. Foraminifers ("Glomospira sp.", Earlandia sp.) are very rare. Intergranular space is filled with drusy mosaic spar.

Oncoids form $10-40 \%$ of the area. They are up to $1.5 \mathrm{~cm}$ large. Cortices consist of dark micrite and sessile foraminifers. Vagile foraminifers were occasionally trapped in oncoids. While most cores cannot be determined, some oncoids formed around bivalve shells and geniculi of dasycladacean algae. The space between oncoids is filled by grainstone. In thin section 1525 it is made of peloids and small oncoids. Foraminifers (Glomospira sp., ?Glomospirella irregularis (Moeller)) are also common, while gastropods and casts of Oncoid floatstone $\left({ }^{*} 13\right) \quad$ small particles filled with sparry calcite are rare. In contrast the grainstone in thin section $1529 \mathrm{~b}$ consists mostly of well-rounded particles preserved as casts filled with sparry calcite and micritic intraclasts. Rare gastropods, dasycladacean algae, echinoderms, and bivalve shells are also present. Foraminifers are less common than in thin section 1525, but represented by the same taxa. The cement is drusy mosaic, in thin section $1529 \mathrm{~b}$ proceeded by acicular rim cement. Some larger vugs are filled with euhedral crystals of zoned (banded) carbonate and crystal silt. Echinoderm plates are overgrown by syntaxial cement.

Grains represent $50 \%$ of the area. They are in point contacts. Except for some large (up to $2.5 \mathrm{~mm}$ ) gastropod shells, the rest of the grains are moderately sorted. Bioclasts and peloids are present in approximately equal amounts. Subangular to subrounded sparitic Peloid-bioclastic grainstone grains are moderately sorted. Bioclasts and peloids are present in approximately equal amounts. Subangular to suricles with microsparitic outlines represent the majority of the former. Among the recognisable bioclasts are foraminifers $(* 12)$ (Glomospira or Hoyenella sp.) and some bivalve fragments. Cockade structures are rimmed by bladed spar and filled partly with crystal silt and partly by subhedral dolomite. Subhedral dolomite also fills the intergranular space. 

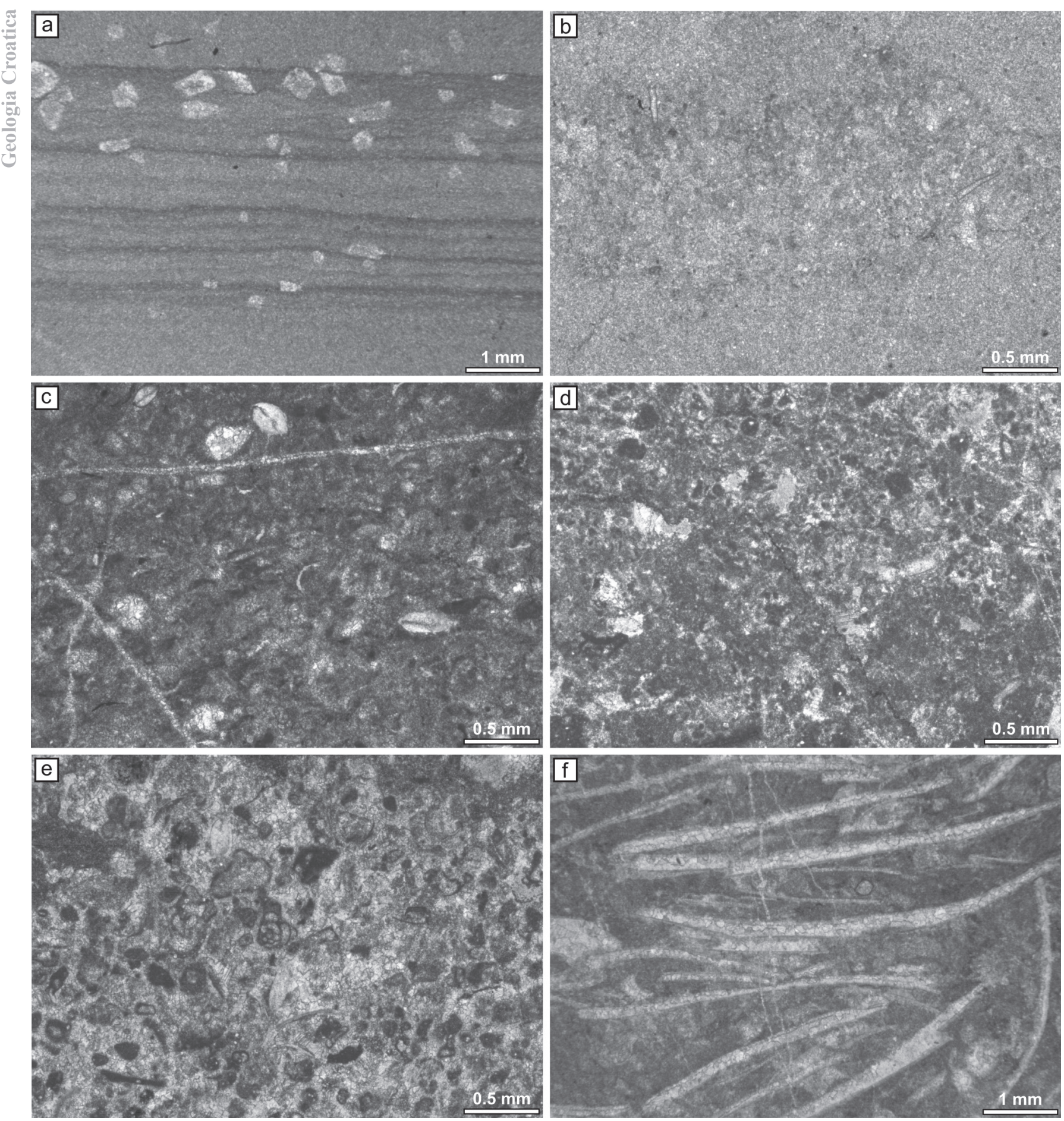

Figure 7. Microfacies of the Velika planina member, section VP1. a) Finely laminated mudstone. Note rhomboidal crystals of calcite. Thin section 1232b. b) Earlandia mudstone. Note the foraminifer Earlandia tintinniformis (Mišik) in the darker lamina. Thin section 1232c. c) Peloid wackestone with ostracods. Thin section 1230. d Partly washed intraclastic-peloid wackestone to packstone. Thin section 1228d. e) Intraclastic-bioclastic grainstone. Note the foraminifer Glomospira sp. in the centre. Thin section 1228c. f) Bivalve floatstone. Thin section 1219.

longer form thicker bundles. Slumping of the sediment is evident, and intraclastic rudstone ("flat-pebble breccia") is locally present. Mudstone and mudstone with filaments and sessile foraminifers (Table 3 ) are the only microfacies types in this section.

\section{Velika planina member - section VP3}

The uppermost part of the Velika planina member was logged in section VP3. The total length of the section is approximately $72 \mathrm{~m}$, but large parts of it are poorly exposed. The bedding, however, remains constant. Platy to thin-bedded dark brown mudstone pre- dominates in the first $16 \mathrm{~m}$ of the section. Subordinate are densely bioturbated beds of micritic limestone $70-100 \mathrm{~cm}$ thick. Above, thin to medium-thick beds of light grey limestone follow. Possible neptunian dykes were observed in one bed. Above the 30-metre mark of the section the limestone becomes light grey in colour. Wavy lamination and birdseye fenestrae are commonly present. Calcarenite is present along with micritic limestone, and oncoids are present in the uppermost part of the section. Microfacies types from the VP3 section are bioturbated mudstone with sparse bioclasts, microbial laminated mudstone (stromatolite), 


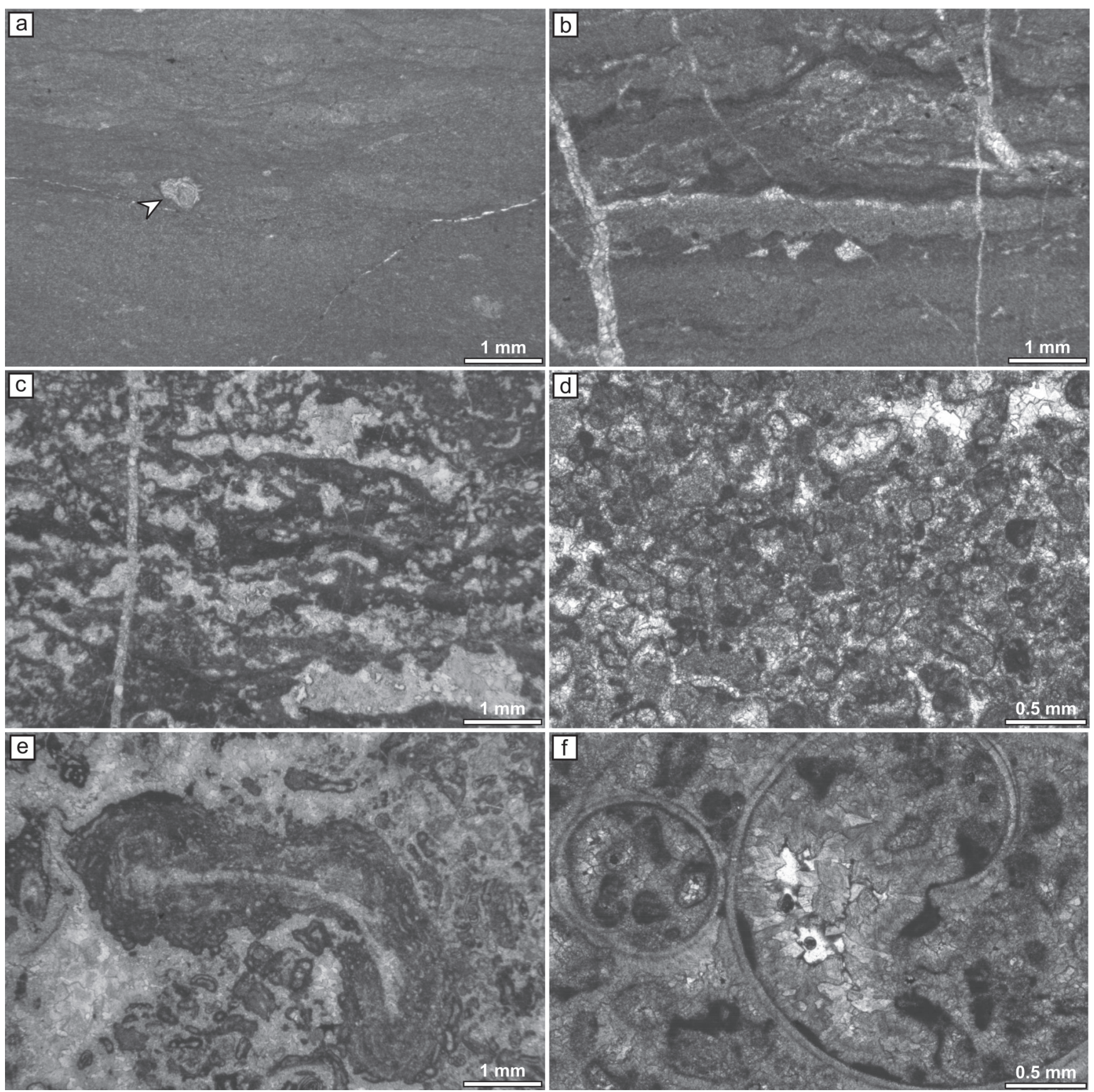

Figure 8. Microfacies of the Velika planina member (upper part), section VP3. a) Bioturbated mudstone with sparse bioclasts. Arrowhead points at the undetermined shell. Thin section 1509. b) Microbial laminated mudstone (stromatolite). Thin section 1511. c: Microbially-bound grainstone with fenestral fabric (stromatolite). Thin section 1528. d) Bioclastic-peloid grainstone. Thin section 1517. e: Oncoid floatstone. A large oncoid, formed mostly by sessile foraminifers, floats in bioclastic-intraclastic grainstone. Thin section 1525. f) Peloid-bioclastic grainstone with gastropod shells. Thin section 1529a.

microbially-bound grainstone with fenestral fabric (stromatolite), partly washed intraclastic-peloid wackestone to packstone, peloid wackestone, bioclastic-peloid grainstone, oncoid floatstone, peloid-bioclastic grainstone, and mud-supported breccia (Table 4; Fig. 8). Citaella dinarica (KOCHANSKY-DEVIDÉ \& PANTIĆ) was found approximately $20 \mathrm{~m}$ higher in a seemingly massive limestone (sample DR-K in Fig. 4).

\section{Macrofossils of the Velika planina member}

Macrofossils can be found throughout the entire Velika planina member; however, they are most frequent in its lower part (section VP1). The trace fossil Chondrites is relatively commonly present in the laminated bituminous limestone of the Velika planina member (Fig. 9c,d). In the lower part of the member there are several beds with accumulated imprints of the bivalves of the genus Modiolus. The shells are only rarely preserved. Bakevellia costata (Fig. 9a) is rarer, as well as some well-preserved crinoid specimens (Fig. 9b). The latter belong to the genera Dadocrinus and Holocrinus. One complete, fully articulated crinoid specimen probably belongs to a new yet undescribed crinoid family. Small ammonoids are extremely rare. The organisms with predominantly chitinous shells are generally well preserved. In some beds we find numerous lingulid inarticulate brachiopods. The inarticulate brachiopods of the genus ?Discinisca are rarer and occur only as single specimens. Other brachiopods are also present, but are not sufficiently preserved for a determination. Crustacean fossils are very rare (Fig. 9d), e.g. mass mortality beds with lobsters in their larval stage. Vertebrate fossils are more common in the 
I lower part of the member. Some specimens are completely articulated and can even bear impressions of soft tissues. Others show partial disarticulation (Fig. 9f). Several remains of sauropterygian reptiles of the order Nothosauroidea were discovered, among them also a complete, fully articulated specimen more than $1 \mathrm{~m}$ long. Several genera of actinopterygian fish are also present (see TINTORI et al., 2014a). These include at least two different species of the genus Saurichthys, together with Eosemionotus, Placopleurus, Furo (Fig. 9e), at least one other neopterygian fish, probably closely related to the basal semionotiform Sangiorgioichthys, and the isolated remains of a coelacanth. Coprolites are quite abundant (Fig. 9g).

\section{DISCUSSION ON CHARACTERISTICS AND EVOLUTION OF THE BASIN}

Triassic rocks, which today form the majority of the KamnikSavinja Alps, were deposited on the continental shelf offshore from the eastern equatorial Pangea (HAAS et al., 1995; STAMPFLI \& BOREL, 2002; STAMPFLI \& KOZUR, 2006). No signs of tectonic activity during the Early Triassic have been reported from this region so far, and a shallow marine mixed carbonatesiliciclastic shelf developed. With the rising sea level, carbonate sedimentation prevailed, giving rise to the Anisian carbonate platforms (BUSER, 1989, 1996). The Velika planina member, under- and overlain by light-coloured peritidal carbonates, testifies
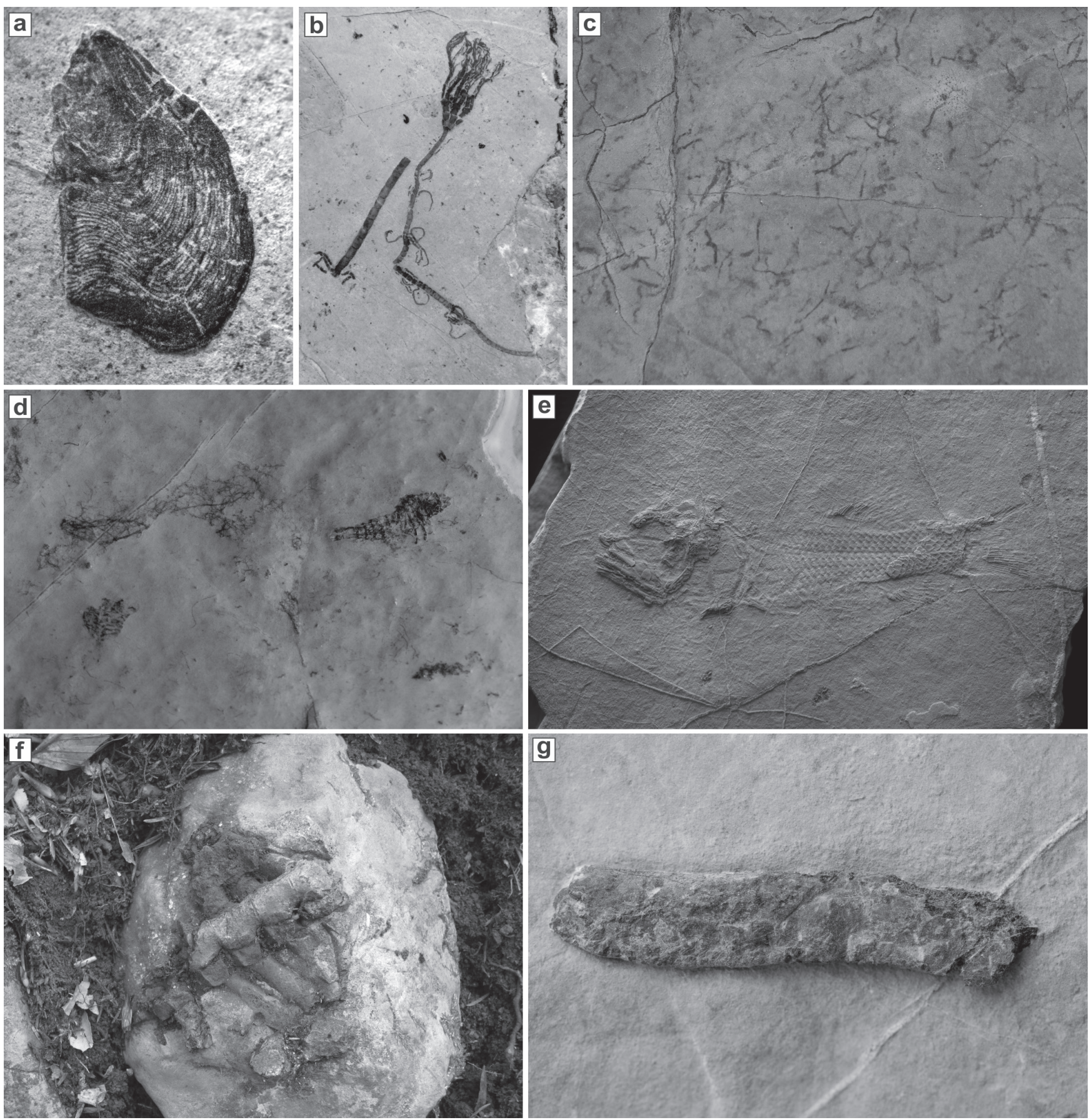

Figure 9. Fossils of the Velika planina member. a) A bivalve Bakevellia costata; length $7 \mathrm{~mm}$. b) An undescribed crinoid; length of the crown 9 mm. c) Chondrites ichnogenus; width of the photo is $4 \mathrm{~mm}$. d) A mass mortality bed with arthropod remains and the trace fossil Chondrites; length of the arthropod on the right is $5 \mathrm{~mm}$. e) A fish of the genus Furo coated by ammonium chloride sublimate; length of the fish is $5 \mathrm{~cm}$. $\mathrm{f}$ ) A sacral region of a sauropterygian reptile of the order Nothosauroidea exposed on the site, length of the specimen is $9 \mathrm{~cm}$. g) A coprolite; length is $5 \mathrm{~cm}$. Image credit: (A, B, E): Jure Žalohar Tomaž Hitij; (C, D, F): Tomaž Hitij. 
to a relative deepening of part of the Anisian platform, probably due to local tectonic subsidence. The finding of the foraminifer Citaella dinarica, both in the underlying rocks and in the transitional interval to the overlying peritidal limestones, confines the deposition of the Velika planina member to the early to middle Anisian (RETTORI, 1995; UENO et al., 2018). This age estimation is consistent with the previously estimated pre-Pelsonian age of the Velika planina member based on the biostratigraphy of fossil fishes (TINTORI et al., 2014a).

The diversity of bioclasts, which include echinoderms and dasycladacean algae, and the light grey colour of the underlying massive or poorly bedded Lower Serla Dolomite suggests initial deposition in an oxygenated shallow marine environment of a carbonate platform. The platform was microbially-dominated, as evidenced by the abundance of microbialites. Bivalve and gastropod lumachellas represent local accumulations of shells.

The absence of breccia at the base of the Velika planina member and a gradual shift from light grey intertidal dolomites to dark bituminous limestone suggest a gradual deepening and the subsequent establishment of a shallow restricted basin. Due to the limited areal extent of the basin, the deepening was probably caused by subsidence along normal faults. Slumping is especially common in the lower and middle part of the Velika planina member (sections VP1, VP2), but was not observed in the uppermost part (section VP3). This could suggest the basin was deeper in its early evolution, or (more likely) initially a more active tectonic subsidence, with a quiescence of tectonic activity later on. The relatively shallow nature of the basin, or at least the lack of connection with an open sea, is supported by the nearabsence or even lack of open-marine plankton and nekton, such as radiolarians and ammonoids, within the Velika planina member and a subsequent gradual transition into oxygenated shallow marine facies within section VP3.

The lower part of the Velika planina member (section VP1) is recognised by the predominance of finely laminated mudstone. The facies association here is similar to the lower Ladinian Meride Limestone of Monte San Giorgio in southern Switzerland/ northern Italy (FURRER, 1995a; STOCKAR, 2010: "laminate lithofacies"), the upper Anisian to lower Ladinian Posanto Formation in eastern Switzerland (BÜRGIN et al., 1995; FURRER, 1995b, 2019), and the Cretaceous Komen limestone in Slovenia (PALCI et al., 2008). At this stage, the water column was likely stratified, with oxygenated near-surface layers and hypoxic to anoxic conditions at the bottom. This is suggested by the preservation of coprolites, as well as articulated vertebrate skeletons. Mudstone, finely laminated mudstone, and Earlandia mudstone all represent background sedimentation. The darker laminae are richer in organic matter and could represent microbial mats on the basin floor. The general absence of larger benthos, the bituminous nature of the limestone, and the fine lamination of the sediment suggest poorly ventilated bottom conditions. This is supported by the profuse presence of Chondrites and the near exclusion of all other trace fossils (BROMLEY \& EKDALE, 1984). However, the local presence of bioturbations, small and rare bivalves, rare crinoids, and even the presence of small benthic foraminifers, such as Earlandia and thin-shelled lagenids, suggest an occasional presence of free oxygen in the uppermost sediment. Earlandia is considered a benthic opportunist (KRAINER \& VACHARD, 2009), and thin-shelled lagenids were tolerant of oxygen-poor conditions (STOCKAR, 2010). Partly washed intraclastic-peloid wackestone to packstone and intraclastic-bioclastic grainstone, on the other hand, indicate deposition in a more en- ergetic setting. Size-sorting of particles indicates transport, and at least some of the bioclasts (e.g., foraminifers Glomospira sp., Endothyracea, and mollusc fragments) probably originated from a better aerated shallow marine environment. We suggest deposition from diluted turbidity currents. Parautochthonous or allochthonous origin is also suggested for peloid wackestone with ostracods, and bivalve floatstone.

Higher up in the succession (sections VP2, VP3), beds are thicker and lamination is less pronounced. More sediment was perhaps shed from the surrounding shallow carbonate platform, or perhaps the conditions on the sea floor became more stable and less restricted. In the last of the logged sections (VP3), the intraplatform basin's deposits gradually give way to the well oxygenated shallow platform carbonates of the platform top. Bioturbation is common in the lower part of the VP3 section, and from the 30-metre mark upwards there are several indicators of peritidal conditions: wavy stromatolites, fenestrae, even a foraminiferal assemblage, dominated by glomospiral forms. Grainstones with various bioclasts, especially fragments of molluscs, again suggests an environment densely populated by benthic invertebrates. Finally, oncoids from the top of the section indicate the presence of waves and/or currents.

Even though the Velika planina member was initially considered to represent a deeper marine basin (HITIJ et al., 2010a), the evidence presented above tends to support the idea of a rather shallow intraplatform basin. This is also supported by the vertebrate remains found in the lower part of the Velika planina member. Among the groups of marine reptiles, only nothosauroids have been identified so far, and these were limited to shallow intraplatform basins and shallow epicontinental seas (RIEPPEL, 1999; ČERNANSKY et al., 2018).

\section{CONCLUSIONS}

The Velika planina member was deposited within a relatively shallow and restricted intraplatform basin during the early to middle Anisian. The basal part of the member is dominated by finely laminated mudstone deposited in a stratified basin with mainly hypoxic to anoxic bottom conditions. Actinopterygian fishes and marine reptiles are well preserved in this facies due to limited bioturbation and scavenging on the sea floor. Moving upwards, restricted facies gradually gives way to well-oxygenated shallow platform carbonates of the Lower Serla Dolomite.

\section{ACKNOWLEDGEMENT}

This research was financially supported by the Slovenian Research Agency (research core funding No. P1-0011 to L.G. and B.C., core funding No. P1-0195 to M.V. and J.Ž., research project 1555-007-P1-0195 to J.Ž.), and Quantectum AG (funding to J.Ž. and B.V.). We thank the technical staff of the Geological Survey of Slovenia for the preparation of the thin sections. Finally, we are very grateful to Heinz FURRER and an anonymous reviewer for their positive attitudes and approaches, as well as for their concrete and constructive remarks.

\section{REFERENCES}

BEARDMORE, S.R. \& FURRER, H. (2016): Taphonomic analysis of Saurichthys from two stratigraphic horizons in the Middle Triassic of Monte San Giorgio, Switzerland.- Swiss J. Geosci., 109, 1-16. doi: 10.1007/s00015-015-0194-Z

BEARDMORE, S.R. \& FURRER, H. (2019): Taphonomic variation within a Middle Triassic fossil lagerstätte (Cassina beds, Meride Limestone) at Monte San Giorgio.- PalZ, 93, 49-67. doi: 10.1007/s12542-018-0415-7

BENTON, M.J. (2016): The Triassic.- Current Biology, 26/23, R1205-R1225. doi: 10.1016/j.cub.2016.10.060 
BENTON, M.J., ZHANG, Q., HU, S., CHEN Z.-Q., WEN, W., LIU, J., HUANG, J., ZHOU, C., XIE, T., TONG, J. \& CHOO, B. (2013): Exceptional vertebrate biotas from the Triassic of China, and the expansion of marine ecosystems after the Permo-Triassic mass extinction.- Earth-Sci. Rev., 125, 199-243. doi: 10.1016/j.earscirev.2013.05.014

BRAYARD, A., KRUMENACKER, L.J., BOTTING, J.P., JENKS, J.F., BYLUND, K.G., FARA, E., VENNIN, E., OLIVIER, N., GOUDEMAND, N., SAUCĖDE, T., CHARBONNIER, S., ROMANO, C., GOGUZHAEVA, L., THUY, B., HAUTMANN, M., STEPHEN, D.A., THOMAZO, C. \& ESCARGUEL, G. (2017): Unexpected Early Triassic marine ecosystem and the rise of the Modern evolutionary fauna.- Sci. Adv., 3, e1602159, 1-11. doi: 10.1126/sciadv.1602159

BROMLEY, R.G. \& EKDALE, A.A. (1984): Chondrites: a trace fossil indicator of anoxia in sediments. - Science; 224, 872-874. doi: 10.1126/science.224.4651.872

BUATOIS, L.A., CARMONA, N.B., CURRAN, H.A., NETTO, R.G., MÁNGANO, M.G. \& WETZEL, A. (2016): The Mesozoic marine revolution.- In: MÁNGANO, M.G. \& BUATOIS, L.A. (eds.): The Trace-Fossil Record of Major Evolutionary Events.- Topics Geobiol., 40, 19-134. doi: 10.1007/978-94-017-9597-5_2

BUFFETAUT, E. \& NOVAK, M. (2008): A cyamodontid placodont (Reptilia: Sauropterygia) from the Triassic of Slovenia.- Palaeontology, 51/6, 1301-1306. doi: 10.1111/j.1475-4983.2008.00819.x

BÜRGIN, T., EICHENBERGER, U., FURRER, H. \& TSCHANZ, K. (1991): Die Prosanto-Formation - eine fischreiche Fossil-Lagerstätte in der Mitteltrias der Silvretta-Decke (Kanton Graubünden, Schweiz).- Eclogae geol. Helv., 84, 921-990. doi: $10.5169 /$ seals- 166804

BUSER, S. (1980): Osnovna geološka karta SFRJ 1:100000. Tolmač za list Celovec (Klagenfurt) L33-53 [Basic Geological Map of SFRY 1:100000, Geology of the Celovec (Klagenfurt) sheet-in Slovenian].--Geološki zavod Ljubljana, Ljubljana, Zvezni geološki zavod, Beograd, $62 \mathrm{p}$.

BUSER, S. (1989): Development of the Dinaric and the Julian carbonate platforms and of the intermediate Slovenian Basin (NW Yugoslavia).- Boll. Soc. Geol. Ital., 40, 313-320.

BUSER, S. (1996): Geology of Western Slovenia and its paleogeographic evolution.In: DROBNE, K., GORIČAN, Š. \& KOTNIK, B. (eds.): International workshop Postojna ,96: The role of impact processes and biological evolution of planet Earth.- ZRC SAZU, Ljubljana, 111-123.

BUSER, S. \& CAJHEN, J. (1977): Osnovna geološka karta SFRJ 1:100000, list Celovec (Klagenfurt) L33-53 [Basic Geological Map of SFRY 1:100000, Celovec (Klagenfurt) sheet - in Slovenian].- Geološki zavod Ljubljana, Ljubljana, Zvezni geološki zavod, Beograd.

CELARC, B. (2004): Geološka zgradba severovzhodnega dela Kamniško - Savinjskih Alp [Geological structure of the northwestern part of the Kamnik-Savinja Alps in Slovenian, with an English abstract].- Unpubl. PhD Thesis, Faculty of Natural Sciences and Engineering, University of Ljubljana, $137 \mathrm{p}$.

CELARC, B. \& GORIČAN, Š. (2007): Diferenciran razpad anizijske (ilirske) karbonatne platforme v Julijskih Alpah (Prisojnik) in Kamniško-Savinjskih Alpah (Križevnik) [Differential disintegration of Anisian (Ilirian) carbonate platform in the Julian Alps (Prisojnik) and in the Kamnik-Savinja Alps (Križevnik) - in Slovenian].- Geološki zbornik, 18, 11-15.

CELARC, B., GORIČAN, Š. \& KOLAR-JURKOVŠEK, T. (2013): Middle Triassic carbonate-platform break-up and formation of small-scale half-grabens (Julian and Kamnik-Savinja Alps, Slovenia).- Facies, 59, 583-610. doi: 10.1007/s10347-0120326-0

CELARC, B., GALE, L. \& KOLAR-JURKOVŠEK, T. (2014): New data on the progradation of the Dachstein carbonate platform (Kamnik-Savinja Alps, Slovenia).Geologija, 57/2, 95-104. doi: 10.5474/geologija.2014.009

ČERŇANSKY, A., KLEIN, N., SOTÁK, J., OLŠAVSKÝ, M., ŠURKA, J. \& HERICH, P. (2018): A Middle Triassic pachypleurosaur (Diapsida: Eosauropterygia) from a restricted carbonate ramp in the Western Carpathians (Gutenstein Formation, Fatric Unit): paleogeographic implications.- Geol. Carpathica, 69/1, 3-16. doi: 10.1515/geoca-2018-0001

DEECKE, W. (1886): Ueber ein von Herrn Oberbergrath Stache in der Steiner Alpen gesammeltes Saurierfragment.- Verh. k. k. geol. Reichsanst., 2, 50-52.

DIEDRICH, C.G. (2012): The Middle Triassic marine reptile biodiversity in the Germanic Basin, in the centre of the Pangaean world. - Cent. Eur. J. Geosci., 4/1, 9-46. doi: 10.2478/s13533-011-0060-0

DUNHAM, R.J. (1962): Classification of carbonate rocks according to depositional texture. In: HAN, W.E. (ed.): Classification of carbonate rocks. A symposium.- Amer. Ass. Petrol. Geol Mem., 108-121. doi: doi.org/10.1306/M1357

DOLŽAN, E. (2017): Geološka zgradba in tektonika severozahodnega dela Kamniških Alp [Structure and tectonics of the north-western part of the Kamnik Alps - in Slovenian, with an English abstract].- Unpubl. MSc Thesis, Faculty of Natural Sciences and Engineering, University of Ljubljana, 73 p.

EMBRY, A.F. \& KLOVAN, J.E. (1971): A late Devonian reef tract on northeastern Banks Island, N.W.T.- Bull. Can. Petrol. Geol., 19, 730-781. doi: 10.35767/gscpgbull.19.4.730
FLÜGEL, E. (2010): Microfacies of carbonate rocks: analysis, interpretation and application ( $2^{\text {nd }}$ edition). - Springer-Verlag, Berlin Heidelberg, $984 \mathrm{p}$.

FODOR, L., JELEN, B., MÁRTON, E., SKABERNE, D., ČAR, J. \& VRABEC, M. (1998): Miocene-Pliocene tectonic evolution of the Slovenian Periadriatic fault: Implications for Alpine-Carpathian extrusion models.- Tectonics, 17/5, 690-709. doi: 10.1029/98TC01605

FURRER, H. (1995a): The Kalkschieferzone (Upper Meride Limestone; Ladinian) near Meride (Canton Ticino, Southern Switzerland) and the evolution of a Middle Triassic intraplatform basin.- Eclogae geol. Helv., 88/3, 827-852. doi: 10.5169/ seals- 167706

FURRER, H. (1995b): The Prosanto-Formation, a marine Middle Triassic Fossil-Lagerstätte near Davos (Canton Graubünden, Eastern Swiss Alps).- Eclogae geol. Helv., 88/3, 681-683. doi: 10.5169/seals-167694

FURRER, H. (2019): Fische und Saurier aus dem Hochgebirge. Fossilien aus der mittleren Trias bei Davos.- Neujahrsbl. Naturforsch. Ges. Zürich, 221, 1-112.

FURRER, H. \& VANDELLI, A. (2014): Guide to the Museum of fossils from Monte San Giorgio Meride.- Fondazione del Monte San Giorgio, Meride, 128 p.

GIANOLLA, P., DE ZANCHE, V. \& MIETTO, P. (1998): Triassic sequence stratigraphy in the Southern Alps (Northern Italy): definition of sequences and basin evolution.In: DE GRACIANSKY, P.C., HARDENBOL, J., JACQUIN, T. \& VAIL, P.R. (eds.): Mesozoic and Cenozoc Sequence Stratigraphy of European Basins.- ${ }^{-}$SEPM Spec. Publ., 60, 719-746. doi: 10.2110/pec.98.02.0719

GORIČAN, Š. \& BUSER, S. (1990): Middle Triassic radiolarians from Slovenia (Yugoslavia).- Geologija, 31-32 (1988/89), 133-197.

HAAS, J., KOVÁCS, S., KRYSTYN, L. \& LEIN, R. (1995): Significance of Late Permian-Triassic facies zones in terrane reconstructions in the Alpine-North Pannonian domain.- Tectonophysics, 242, 19-40. doi: 10.1016/0040-1951(94)00157-5

HAGDORN, H. \& RIEPPEL, O. (1999): Stratigraphy of marine reptiles in the Triassic of Central Europe.- Zbl. Geol. Paläont. Teil I, 7-8, 651-678.

HITIJ, T. \& RENESTO, S. (2010): Plazilci Strelovške formacije [Reptiles of the Strelovec Formation - in Slovenian, with an English abstract].- In: GREGORI, J. (ed.): The kingdom of Tethys. The fossilized world of Triassic vertebrates from the Kamniško-Savinjske Alps.- Scopolia, J. Slovenian Mus. Nat. History, Suppl. 5, 68-83.

HITIJ, T., KRIŽNAR, M., ŽALOHAR, J., RENESTO, S. \& TINTORI, A. (2010a): Horizont Velike planina - dom triasnih morskih pošasti [The Velika planina horizon - home to the Triassic sea monsters - in Slovenian, with an English abstract].- In: GREGORI, J. (ed.): The kingdom of Tethys. The fossilized world of Triassic vertebrates from the Kamniško-Savinjske Alps. Scopolia, J. Slovenian Mus. Nat. History, Suppl. 5, 68-83.

HITIJ, T., KRIŽNAR, M. \& ŽALOHAR, J. (2010b): Bogastvo fosilov v ladinijskih plasteh Kamniško-Savinjskih Alp in Južnih Karavank [Fossils in Ladinian beds of the Kamniško-Savinjske Alps and Southern Karavanke Mountains - in Slovenian, with an English abstract].- In: GREGORI, J. (ed.): The kingdom of Tethys. The fossilized world of Triassic vertebrates from the Kamniško-Savinjske Alps. Scopolia, J. Slovenian Mus. Nat. History, Suppl. 5, 157-169.

HUGI, J., SCHEYER, T.M., SANDER, P.M., KLEIN, N. \& SÁNCHEZ-VILLAGRA, M.R. (2011): Long bone microstructure gives new insights into the life of pachypleurosaurids from the Middle Triassic of Monte San Giorgio, Switzerland/Italy.C. R. Palevol., 10/5-6, 413-426. doi: 10.1016/j.crpv.2011.03.009

JURKOVŠEK, B. (1984): Langobardske plasti z daonelami in pozidonijami v Sloveniji [Langobardian beds with daonellas and posidonias in Slovenia - in Slovenian, with an English abstract].- Geologija, 27, 41-95.

KREINER, K. \& VACHARD, D. (2009): The Lower Triassic Werfen Formation of the Karawanken Mountains (Southern Austria) and its disaster survivor microfossils, with emphasis on Postcladella n. gen. (Foraminifera, Miliolata, Cornuspirida).Rev. Micropaléont., 54/2, 59-85. doi: 10.1016/j.revmic.2008.11.001

KRIŽNAR, M. (2009): Karnijski vretenčarji iz Poljanske doline [Carnian vertebrates from the Poljanska dolina valley - in Slovenian].- Društvene novice, 40, 21-22.

LIPOLD, M.V. (1856): Geologische Skizze des Gebietes von Sulzbach.- Jahrb. d. Geol. Reichsanst., 7, 169-171.

LIU, J., RIEPPEL, O., JUANG, D.-Y., AITCHISON, J.C., MOTANI, R., ZHANG, Q.-Y., ZHOU, C.-Y. \& SUN, Y.-Y. (2011): A new pachypleurosaur (Reptilia: Sauropterygia) from the lower Middle Triassic of southwestern China and the phylogenetic relationships of Chinese pachypleurosaurs.- J. Vertebr. Paleontol., 31, 292-302. doi: 10.1080/02724634.2011.550363

MIKLAVC, P., CELARC, B. \& SSMUC, A. (2016): Anisian Strelovec Formation in the Robanov kot, Savinja Alps (Northern Slovenia).- Geologija, 59/1, 23-34. doi: 10.5474/geologija.2016.002

MIOČ, P. (1983): Osnovna geološka karta SFRJ 1:100000. Tolmač za list Ravne na Koroškem L33-54 [Basic Geological Map of SFRY 1:100000, Geology of the Ravne na Koroškem sheet -in Slovenian].- Geološki zavod Ljubljana, Ljubljana, Zvezni geološki zavod, Beograd, $69 \mathrm{p}$.

MIOČ, P., ŽNIDARČIČ, M. \& JERŠE, Z. (1983): Osnovna geološka karta SFRJ 1:100000, list Ravne na Koroškem L33-54 [Basic Geological Map of SFRY 
1:100000, Ravne na Koroškem sheet - in Slovenian].- Geološki zavod Ljubljana, Ljubljana, Zvezni geološki zavod, Beograd.

MOTANI, R. (2009): The evolution of marine reptiles.- Evo. Edu. Outreach, 2, 224-235. doi: 10.1007/s12052-009-0139-y

PALCI, A., JURKOVŠEK, B., KOLAR-JURKOVŠEK, T. \& CALDWELL, M.W. (2008): New palaeoenvironmental model for the Komen (Slovenia) Cenomanian (Upper Cretaceous) fossil lagerstätte-- Cretac. Res., 29, 316-328. doi: 10.1016/j. cretres.2007.05.003

PAYNE, J.L. \& VAN DE SCHOOTBRUGGE, B. (2007): Life in Triassic Oceans: Links between planktonic and benthic recovery and radiation.- In: FALKOWSKI, P. \& KNOLL, A.H. (eds.): Evolution of Primary Producers in the Sea. Academic Press, Amsterdam, 165-189. doi: 10.1016/B978-012370518-1/50010-2

PLACER, L. (1999): Contribution to the macrotectonic subdivision of the border region between Southern Alps and External Dinarides.- Geologija, 41, 223-255. doi: 10.5474/geologija.1998.013

PONTON, M. (2014): Analisi strutturale profonda delle Dinaridi Esterne fra Alpi e prealpi Giulie (Italia e Slovenia) [Depth stzructural analysis of the External Dinaric Chain in Julian Alps and Pre-Alps (Italy and Slovenia) - in Italian, with an English extended abstract].- Gortania Geologia, Paleontologia, Paletnologia, 36, $23-34$.

PREMRU, U. (1983a): Osnovna geološka karta SFRJ 1:100000, list Ljubljana L33-66 [Basic Geological Map of SFRY 1:100000, Ljubljana sheet - in Slovenian].Geološki zavod Ljubljana, Ljubljana, Zvezni geološki zavod, Beograd.

PREMRU, U. (1983b): Osnovna geološka karta SFRJ 1:100000. Tolmač za list Ljubljana L33-66 [Basic Geological Map of SFRY 1:100000, Geology of the Ljubljana sheet - in Slovenian].- Geološki zavod Ljubljana, Ljubljana, Zvezni geološki zavod, Beograd, $75 \mathrm{p}$.

PRIMOŽIČ, J. (2020): Biostratigrafska in sedimentološka analiza globljemorskih triasnih plasti pri Preddvoru [Biostratigraphic and sedimentological analysis of Triassic beds at Preddvor - in Slovenian, with an English abstract].- Unpubl. Diploma Thesis, Faculty of Natural Sciences and Engineering, University of Ljubljana, 34 p.

RAMOVŠ, A. (1973): Biostratigrafske značilnosti triasa v Sloveniji [Biostratigraphische Charakteristik der Trias in Slowenien - in Slovenian, with a German summary].Geologija, 16, 379-388.

RAMOVŠ, A. \& JAMNIK, A. (1991): The first proof of deeper marine Norian (Upper Triassic) beds with conodonts and holothurian skeletons in the Kamnik Alps (Slovenia).- Mining and Metallurgy Quarterly, 38/3, 365-367.

RENESTO, S., BINELLI, G. \& HAGDORN, H. (2014): A new pachypleurosaur from the Middle Triassic Besano Formation of Northern Italy.- N. Jb. Geol. Paläont. Abh., 271/2, 151-168. doi: 10.1127/0077-7749/2014/0382

RETTORI, R. (1995): Foraminiferi del Trias inferiore e medio della Tetide: revisione tassonomica, stratigrafia ed interpretazione filogenetica [Lower and Middle Triassic foraminifers of the Tethys: taxonomic revision, stratigraphy and phylogenetic interpretaton - in Italian].- Université de Geneve, Publications du Départment de Géologie et Paléontologie, 18 (1995), 1-107.

RIEPPEL, O. (1997): Part II: Sauropterygia. Introduction.- In: CALLAWAY, J.M. \& NICHOLLS, E.L. (eds.): Ancient Marine Reptiles. Academic Press, San Diego, California, 107-119.

RIEPPEL, O. (1999): Phylogeny and paleobiogeography of Triassic Sauropterygia: problems solved and unresolved.- Palaeogeogr. Palaeoclimatol. Palaeoecol., 153, 1-15. doi: 10.1016/S0031-0182(99)00067-X

RÖHL, H.-J., SCHMID-RÖHL, A., FURRER, H., FRIMMEL, A., OSCHMANN, W. \& SCHWARK, L. (2001): Microfacies, geochemistry and palaeoecology of the Middle Triassic Grenbitumenzone from Monte San Giorgio (Canton Ticino, Switzerland).- Geol. Insubr., 6/1, 1-13.

ROLLE, F. (1857): Geologische Untersuchungen in der Gegend zwischen Weitenstein, Windisch-Gratz, Cilli und Oberburg in Unter-Steiermark.- Jahrb. d. Geol. Reichsanst., $8 / 3,403-465$.
SCHMID, S.M., BERNOULLI, D., FÜGENSCHUH, B., MATENCO, L., SCHEFER, S., SCHUSTER, R., TISCHLER, M. \& USTASZEWSKI, K. (2008): The Alpine-Carpathian-Dinaric orogenic system: correlation and evolution of tectonic units.- Swiss J. Geosci., 101, 139-183. doi: 10.1007/s00015-008-1247-3

STAMPFLI, G.M. \& BOREL, G.D. (2002): A plate tectonic model for the Paleozoic and Mesozoic constrained by dynamic plate boundaries and restored synthetic oceanic isochrons.- Earth Planet. Sci. Lett., 196, 17-33. doi: 10.1016/S0012821X(01)00588-X

STAMPFLI, G.M. \& KOZUR, H.W. (2006): Europe from the Variscan to Alpine cycles.In: GEE, D.G. \& STEPHENSON, R.A. (eds.): European Lithosphere Dynamics.Geol. Soc. Mem., 32, 57-82. doi: 10.1144/GSL.MEM.2006.032.01.04

STOCKAR, R. (2010): Facies, depositional environment, and palaeoecology of the Middle Triassic Cassina beds (Meride Limestone, Monte San Giorgio, Switzerland).Swiss J. Geosci., 103, 101-119. doi: 10.1007/s00015-010-0008-2

STUBBS, T.L. \& BENTON, M.J. (2016): Ecomorphological diversifications of Mesozoic marine reptiles: the roles of ecological opportunity and extinction.- Paleobiology, 42/4, 547-573. doi: doi.org/10.1017/pab.2016.15

TELLER, F. (1885): Fossilführende Horizonte in der oberen Trias der Sanntataler Alpen.- Verhandl. Geol. Reichsanst., 355-361.

TELLER, F. (1898a): Geologische Spezialkarte der k. k. Österreichisch - Ungarischen Monarchie 1:75 000, Blatt Eisenkappel und Kanker, Zone 20, Col. 11 [Geological Map of Österreichisch - Ungarischen Monarchie 1:75 000, Eisenkappel and Kranj sheet - in German].- K. k. Geologische Reichsanstalt, Wien.

TELLER, F. (1898b): Geologische Spezialkarte der k. k. Österreichisch - Ungarischen Monarchie 1:75 000. Erläuterungen zur Blatt Eisenkappel und Kanker [Geological Map of Österreichisch - Ungarischen Monarchie 1:75 000, Geology of the Eisenkappel and Kranj - in German].- K. k. Geologische Reichsanstalt, Wien, 150 p.

TINTORI, A., HITIJ, T., JIANG, D., LOMBARDO, C. \& SUN, Z. (2014a): Triassic actinopterygian fishes: the recovery after the end-Permian crisis.- Integr. Zool., 9/4, 394-411. doi: 10.1111/1749-4877.12077

TINTORI, A., HUANG, J.D., JIANG, D.Y., SUN, Z.Y., MOTANI, R. \& CHEN, G. (2014b): A new Saurichthys (Actinopterygii) from the Spathian (Early Triassic) of Chaohu (Anhui Province, China).- Riv. Ital. Paleont. Strat., 120/2, 157-64. doi: 10.13130/2039-4942/6057

UENO, K., KAMATA, Y., UNO, K., CHAROENTITIRAT, T., CHARUSIRI, P., VILAYKHAM, K. \& MARTINI, R. (2018): The Sukhothai Zone (Permian-Triassic island-arc domain of Southeast Asia) in Northern Laos: Insights from Triassic carbonates and foraminifers.- Gondwana Res., 61, 88-99. doi: 10.1016/j. gr.2018.04.013

VRABEC, M. \& FODOR, L. (2006): Late Cenozoic tectonics of Slovenia: structural styles at the Northeastern corner of the Adriatic microplate.- In: PINTER, N., GRENERCZY, G., WEBER, J., STEIN, S. \& MEDEK, D. (eds.): The Adria microplate: GPS geodesy, tectonics and hazards.- NATO Sci. Ser., IV, Earth Environment. Sci., 61, 151-168. doi: 10.1007/1-4020-4235-3_10

VRABEC, M., PAVLOVČIČ PREŠEREN, P. \& STOPAR, B. (2006): GPS study (19962002) of active deformation along the Periadriatic fault system in northeastern Slovenia: tectonic model.- Geol. Carpathica, 57/1, 57-65.

WRIGHT, V.P. (1992): A revised classification of limestones.- Sed. Geology, 76, 177-185. doi: 10.1016/0037-0738(92)90082-3

ŽALOHAR, J. \& CELARC, B. (2010): Geološka zgradba Kamniško-Savinjskih Alp [Geological structure of the Kamniško-Savinjske Alps - in Slovenian, with an English abstract].- In: GREGORI, J. (ed.): The kingdom of Tethys. The fossilized world of Triassic vertebrates from the Kamniško-Savinjske Alps.- Scopolia, J. Slovenian Mus. Nat. History, Suppl. 5, 43-51. 